\title{
AMPA Receptor Current Density, Not Desensitization, Predicts Selective Motoneuron Vulnerability
}

\author{
Wim Vandenberghe, ${ }^{1,3}$ Eva C. Ihle, ${ }^{2}$ Doris K. Patneau, ${ }^{2}$ Wim Robberecht, ${ }^{3}$ and James R. Brorson ${ }^{1}$ \\ Departments of ${ }^{1}$ Neurology and ${ }^{2 N e u r o b i o l o g y, ~ P h a r m a c o l o g y ~ a n d ~ P h y s i o l o g y, ~ T h e ~ U n i v e r s i t y ~ o f ~ C h i c a g o, ~ C h i c a g o, ~ I l l i n o i s ~}$ \\ 60637, and 32Department of Neurology, University of Leuven, 3000 Leuven, Belgium
}

\begin{abstract}
Spinal motoneurons are more susceptible to AMPA receptormediated injury than are other spinal neurons, a property that has been implicated in their selective degeneration in amyotrophic lateral sclerosis (ALS). The aim of this study was to determine whether this difference in vulnerability between motoneurons and other spinal neurons can be attributed to a difference in AMPA receptor desensitization and/or to a difference in density of functional AMPA receptors. Spinal motoneurons and dorsal horn neurons were isolated from embryonic rats and cultured on spinal astrocytes. Single-cell RT-PCR quantification of the relative abundance of the flip and flop isoforms of the AMPA receptor subunits, which are known to affect receptor desensitization, did not reveal any difference between the two cell populations. Examination of AMPA receptor desensitization by patch-clamp
\end{abstract}

electrophysiological measurements on nucleated and outsideout patches and in the whole-cell mode also yielded similar results for the two cell groups. However, AMPA receptor current density was two- to threefold higher in motoneurons than in dorsal horn neurons, suggesting a higher density of functional AMPA receptors in motoneuron membranes. Pharmacological reduction of AMPA receptor current density in motoneurons to the level found in dorsal horn neurons eliminated selective motoneuron vulnerability to AMPA receptor activation. These results suggest that the greater AMPA receptor current density of spinal motoneurons may be sufficient to account for their selective vulnerability to AMPA receptor agonists in vitro.

Key words: amyotrophic lateral sclerosis; excitotoxicity; kainate; glutamate; kinetic; spinal cord; dorsal horn; rat; culture
Motoneurons selectively die in amyotrophic lateral sclerosis (ALS), a fatal neurodegenerative disease. AMPA receptormediated excitotoxicity has been implicated in the selective motoneuron loss of ALS (Rothstein, 1996). Motoneurons are more vulnerable to AMPA receptor agonists than other spinal neurons, both in vivo (Hugon et al., 1989; Ikonomidou et al., 1996) and in vitro (Rothstein et al., 1993; Carriedo et al., 1996; Bar-Peled et al., 1999; Carriedo et al., 2000; Vandenberghe et al., 2000). However, the mechanisms underlying this selective susceptibility of spinal motoneurons to AMPA receptor-mediated death are poorly understood. In principle, the difference in vulnerability to AMPA receptor agonists between motoneurons and other spinal neurons must result from differences in AMPA receptor expression and/or from differences in events occurring "downstream" from AMPA receptor-mediated cation influx. Substantial interest has focused on the possibility that selective motoneuron vulnerability might result from predominant expression of highly $\mathrm{Ca}^{2+}$-permeable AMPA receptors and a lack of the AMPA receptor subunit GluR2 in this cell type (Williams et al., 1997). However, we have recently shown that there is no difference between spinal motoneurons and dorsal horn neurons in terms of whole-cell relative $\mathrm{Ca}^{2+}$ permeability of AMPA receptors or relative abundance of GluR2 mRNA (Vandenberghe et al., 2000).

Another property of AMPA receptors that modulates the magnitude of AMPA receptor-mediated $\mathrm{Ca}^{2+}$ influx and might affect vulnerability to excitotoxicity is their desensitization to prolonged agonist stimulation. Glutamate-induced AMPA receptor-mediated currents rapidly desensitize in the continued presence of glutamate

Received May 3, 2000; revised June 30, 2000; accepted July 14, 2000.

This work was supported by the ALS Association and by National Institute of Neurological Disease and Stroke Grant NS36260 (J.R.B.). W.V. is supported as Aspirant of the Fund for Scientific Research (FWO)-Flanders and by the D. Collen Research Foundation. W.R. is supported as a Clinical Investigator of the FWO-Flanders.

Correspondence should be addressed to Dr. James R. Brorson, Department of Neurology, MC2030, The University of Chicago, 5841 S. Maryland Avenue, Chicago, IL 60637. E-mail: jbrorson@neurology.bsd.uchicago.edu.

Copyright (C) 2000 Society for Neuroscience $0270-6474 / 00 / 207158-09 \$ 15.00 / 0$ to steady-state levels far smaller than the peak currents (Kiskin et al., 1986; Trussell et al., 1988; Patneau and Mayer, 1991). AMPA receptor desensitization protects neurons against the excitotoxic effects of AMPA receptor activation, as demonstrated by the fact that pharmacological reduction of desensitization enhances AMPA receptor-mediated neuronal death (Zorumski et al., 1990; Brorson et al., 1995; Carriedo et al., 2000). Different neuronal cell types diverge widely in the desensitization properties of their AMPA receptors (Raman et al., 1994; Geiger et al., 1995). This divergence in AMPA receptor desensitization properties arises from different expression patterns of the four AMPA receptor subunits and their flip/flop alternative splice variants (Sommer et al., 1990; Mosbacher et al., 1994; Geiger et al., 1995). The differences in AMPA receptor desensitization between neuronal cell types could be an important determinant of selective neuronal vulnerability, as has been shown in cerebellar cultures (Brorson et al., 1995). In motoneurons, some qualitative studies have suggested high levels of the flip splice variants of AMPA receptor subunits, which might contribute to expression of AMPA receptors with relatively less desensitization (Tölle et al., 1993; Jakowec et al., 1995). However, analyses of the AMPA receptor desensitization characteristics of mammalian motoneurons have not been reported. Therefore, the first aim of the present study was to test the hypothesis that motoneurons are selectively vulnerable to AMPA receptor agonists because their AMPA receptors desensitize more slowly or less completely than those of other spinal neurons.

A second hypothesis examined in this study attributes the selective vulnerability of spinal motoneurons to the high number or density of AMPA receptors expressed by this cell type. Functional AMPA receptor density (the number of functional AMPA receptors per unit of cell surface area) can best be estimated by electrophysiological measurements of AMPA receptor current density. Our previous preliminary evidence suggested a considerably higher AMPA receptor current density in motoneurons than in spinal dorsal horn neurons (Vandenberghe et al., 2000). In the present study, we provide a detailed analysis of AMPA receptor current density in motoneurons and dorsal horn neurons and investigate the role of this parameter in selective motoneuron vulnerability. 


\section{MATERIALS AND METHODS}

\section{Cell cultures}

Spinal motoneurons and dorsal horn neurons were dissociated from 15-dold Holtzmann rat embryos and cultured as described previously (Vandenberghe et al., 1998, 2000). The procedures that were followed were in accordance with a protocol approved by the University of Chicago Institutional Animal Care and Use Committee. A motoneuron-enriched neuronal population was purified from the ventral spinal cord by centrifugation on a $6.5 \%$ metrizamide (Sigma, St. Louis, MO) cushion and cultured on preestablished spinal astrocytic feeder layers. Dorsal horn neurons were dissociated from the dorsal half of the spinal cords of the same embryos. The preparation and culture procedures for dorsal horn neurons were the same as for motoneurons except that the metrizamide centrifugation step was omitted. All cultures were kept in a $6 \% \mathrm{CO}_{2}$ humidified incubator at $37^{\circ} \mathrm{C}$. All experiments were performed on neurons after $10-13 \mathrm{~d}$ in vitro.

\section{Single-cell RT-PCR and restriction analysis}

Aspiration of the cell content into the patch pipette, reverse transcription, and first-round PCR for quantification of the relative abundance of the four AMPA receptor subunits were performed as described previously in detail (Brorson et al., 1999; Vandenberghe et al., 2000). The relative abundance of the flip and flop splice variants of each AMPA receptor subunit was quantified according to a previously published protocol (Lambolez et al., 1996; Brorson et al., 1999), with minor modifications. In brief, bands of successful first-round PCR reactions were excised from the agarose gel and purified with the QIAquick gel extraction kit (Qiagen, Valencia, CA). The purified products of first-round PCR were subjected to subunit-specific, second-round PCR reactions, using subunit-specific upstream primers and a common downstream primer (Brorson et al., 1999). Second-round PCR reactions were performed in a $100 \mu \mathrm{l} \mathrm{PCR} \mathrm{mix} \mathrm{con-}$ taining PCR buffer (Perkin-Elmer, Foster City, CA), 10 pmol of each primer, $0.05 \mathrm{~mm}$ dNTPs (Amersham Pharmacia Biotech), 2.5 U Taq polymerase (Perkin-Elmer, Norwalk, CT), and $1.5 \mathrm{~mm} \mathrm{MgCl}$, for 30 cycles $\left(94^{\circ} \mathrm{C}\right.$ for $30 \mathrm{sec}, 55^{\circ} \mathrm{C}$ for $30 \mathrm{sec}, 72^{\circ} \mathrm{C}$ for $\left.45 \mathrm{sec}\right)$, followed by $72^{\circ} \mathrm{C}$ for $10 \mathrm{~min}$. For GluR4 an annealing temperature of $60^{\circ} \mathrm{C}$ instead of $55^{\circ} \mathrm{C}$ was used. The second-round PCR products were ethanol-precipitated and resuspended in $\mathrm{H}_{2} \mathrm{O}$ for subsequent restriction analysis. The specificity of the second-round PCR for each subunit was verified for each sample by complete $(>95 \%)$ digestion with a subunit-specific restriction enzyme (BglI for GluR1, Bsp1286I for GluR2, Eco47III for GluR3, and EcoRI for GluR4). Products of second-round PCR were then digested with restriction enzymes that distinguish the flip and flop splice variants of each subunit. The flip/flop proportion of the GluR1 subunit was determined by digesting the 634 bp GluR1 product with $B f a$ I (which selectively cuts GluR1 flip into fragments of 570 and $64 \mathrm{bp}$ ) and MseI (which selectively cuts GluR1 flop into fragments of 579 and $55 \mathrm{bp}$ ). The $634 \mathrm{bp}$ GluR2 product was digested with MseI (which cuts GluR2 flip into fragments of 585 and $49 \mathrm{bp}$, and GluR2 flop into fragments of 516, 69, and 49 bp), the 651 bp GluR3 fragment was digested with MseI (which cuts GluR3 flip into fragments of 586 and $65 \mathrm{bp}$, and GluR3 flop into fragments of 518, 65, 56, and $12 \mathrm{bp}$ ), and the 626 bp GluR4 fragment was digested with $\mathrm{HpaI}$ (which selectively cuts GluR4 flop into fragments of 558 and $68 \mathrm{bp}$ ). HpaI digestion of GluR4 product was always performed in parallel with $\mathrm{HpaI}$ digestion of a pure GluR4 flop fragment to verify complete digestion of GluR4 flop. Restriction digestions with $B f a \mathrm{I}, M s e \mathrm{I}$, and $\mathrm{Hpa \textrm {I }}$ were performed overnight at $37^{\circ} \mathrm{C}$. The digestion products were separated on $5 \%$ polyacrylamide gels and quantified by digital fluorimetric scanning (corrected for length differences).

\section{Electrophysiology}

Recording from patches. For recording from membrane patches, borosilicate glass pipettes were coated with Sylgard and fire-polished. Electrodes typically had a resistance of 2-4 M $\Omega$ when filled with intracellular solution, which contained (in $\mathrm{mM}$ ): $115 \mathrm{CsMeSO}_{3}, 15 \mathrm{CsCl}, 10 \mathrm{CsF}, 10$ HEPES, $5 \mathrm{Cs}_{4}$ BAPTA, $0.5 \mathrm{CaCl}_{2}, 3 \mathrm{MgCl}_{2}$ and $2 \mathrm{Na}_{2} \mathrm{ATP}, \mathrm{pH} 7.2$ with $\mathrm{CsOH}$; osmolarity $305-310 \mathrm{mOsm} / 1$. Neurons were voltage-clamped in the whole-cell configuration at $-60 \mathrm{mV}$ using an Axopatch 200A amplifier (Axon Instruments, Foster City, CA) and standard techniques (Hamill et al., 1981). Nucleated macropatches (Sather et al., 1992; Patneau et al., 1993 ) or conventional outside-out patches (Hamill et al., 1981) were pulled after achieving the whole-cell configuration. All recordings from patches were made at room temperature at a holding potential of $-60 \mathrm{mV}$ in an extracellular solution containing (in $\mathrm{mM}$ ): $145 \mathrm{NaCl}, 3 \mathrm{KCl}, 2 \mathrm{CaCl}_{2}, 1$ $\mathrm{MgCl}_{2}, 10 \mathrm{HEPES}$, and 10 glucose, $\mathrm{pH} 7.4$ with $\mathrm{NaOH}$, supplemented with MK-801 $(10 \mu \mathrm{M})$, tetrodotoxin $(0.5 \mu \mathrm{M})$, and $\mathrm{Cd}^{2+}(100 \mu \mathrm{M})$ to block NMDA receptors, voltage-gated $\mathrm{Na}^{+}$channels and $\mathrm{Ca}^{2+}$ channels, respectively. Resistance in series with the patch was typically 4-8 M $\Omega$ and was compensated by $60-90 \%$. Data for on-line recording were filtered at $3 \mathrm{kHz}$ and sampled at $20-40 \mathrm{kHz}$ using pCLAMP (Axon Instruments).

For fast perfusion of patches, solutions were gravity fed through fourbarreled, square glass tubing pulled to a width of $\sim 100 \mu \mathrm{m}$ per barrel. The tubing was mounted on a piezo translator driven by a $100 \mathrm{~V}$ power supply (PZ 100; Burleigh Instruments, Fishers, NY). A patch was positioned in the control solution stream, near the interface between control an agonist-containing solutions. The interface between solutions was rapidly moved across the patch during charging and discharging of the piezo element. This system achieves solution exchange on a patch in $<300 \mu \mathrm{sec}$, as determined from the $10-90 \%$ rise and decay time for a sodium concentration change in the presence of kainate. To apply different solutions to the patch, the recording pipette was displaced vertically between the upper and lower pair of barrels. At the end of each recording, the patch was disrupted, and junction potentials were recorded to verify the correct positioning of the patch for optimal solution exchange (the $\left[\mathrm{Na}^{+}\right]$was $\sim 6$ $\mathrm{mm}$ lower in the control solutions). Data were excluded if the junction potentials indicated that the patch was not properly positioned at the solution interface.

Whole-cell recordings. Whole-cell electrophysiological experiments were performed in the continuous single-electrode voltage-clamp mode using an Axopatch 1D amplifier (Axon Instruments), as described previously (Vandenberghe et al., 2000). All recordings were performed at room temperature, using unpolished borosilicate pipettes placed at the cell soma. Pipettes had a resistance of $1.8-2.5 \mathrm{M} \Omega$ when filled with intracellular solution, which consisted of (in mM): $120 \mathrm{CsF}, 3 \mathrm{MgCl}_{2}, 5$ EGTA, and 10 HEPES, $\mathrm{pH}$ adjusted to 7.25 with $12 \mathrm{~mm} \mathrm{CsOH}$. $\mathrm{Ag}-\mathrm{AgCl}$ electrodes served as pipette electrode and ground electrode. The latter was connected to the bath by means of a $3 \mathrm{mM} \mathrm{KCl}$-agar bridge. Cells were accepted for study if after forming a $G \Omega$ seal and breaking into the whole-cell mode a stable seal persisted with a whole-cell resistance of at least $120 \mathrm{M} \Omega$ and a series resistance of $<10 \mathrm{M} \Omega$. Series resistance was compensated to $\sim 30-$ $40 \%$, yielding a final, effective series resistance of $<7 \mathrm{M} \Omega$. Agonists were applied with a solenoid valve-based system via a theta tube applicator.

The usual extracellular perfusion buffer was the same $145 \mathrm{~mm} \mathrm{Na}^{+}$ buffer used for recording from patches. A critical issue in these whole-cell studies was the adequacy of voltage clamp, because agonist-evoked currents in $145 \mathrm{mM} \mathrm{Na}^{+}$at holding potentials of -60 to $-90 \mathrm{mV}$ could exceed $5 \mathrm{nA}$ in amplitude. Two different approaches were used to reduce the driving force for agonist-evoked currents. The first approach was to record in $145 \mathrm{~mm} \mathrm{Na}^{+}$at a depolarized holding potential $(-10 \mathrm{mV})$; the reversal potential of AMPA receptor-mediated currents in $145 \mathrm{mM} \mathrm{Na}{ }^{+}$was $+12.2 \pm 1.2 \mathrm{mV}$ in motoneurons $(n=8)$ and $+11.6 \pm 0.7 \mathrm{mV}$ in dorsal horn neurons $(n=11)$. The second approach was to reduce the $\mathrm{Na}^{+}$ concentration of the extracellular solution. Where indicated, recordings were made in $20 \mathrm{mM} \mathrm{Na}^{+}$at $-80 \mathrm{mV}$ or in $10 \mathrm{mM} \mathrm{Na}^{+}$at $-90 \mathrm{mV}$. The $20 \mathrm{mM} \mathrm{Na}^{+}$solution contained (in $\mathrm{mm}$ ): $15.3 \mathrm{NaCl}, 4.7 \mathrm{NaOH}, 2 \mathrm{CaCl}_{2}, 10$ HEPES, 10 glucose, and 228 sucrose, $\mathrm{pH} 7.4$; osmolarity $315 \mathrm{mOsm} / \mathrm{l}$; the reversal potential of AMPA receptor-mediated currents in this solution was $-43.2 \pm 1.1 \mathrm{mV}$ in motoneurons $(n=9)$ and $-41.8 \pm 0.9 \mathrm{mV}$ in dorsal horn neurons $(n=9)$. The $10 \mathrm{mM} \mathrm{Na}^{+}$solution contained (in $\mathrm{mM}$ ): 7.5 $\mathrm{NaCl}, 2.5 \mathrm{NaOH}, 1 \mathrm{Ca}(\mathrm{OH})_{2}, 10 \mathrm{HEPES}, 10$ glucose, and 233 sucrose, $\mathrm{pH}$ 7.4; osmolarity $305 \mathrm{mOsm} / 1$; the reversal potential of AMPA receptormediated currents in this solution was $-62.0 \pm 1.0 \mathrm{mV}$ in motoneurons $(n=7)$ and $-62.7 \pm 0.6 \mathrm{mV}$ in dorsal horn neurons $(n=6)$. By recording in $145 \mathrm{mM} \mathrm{Na}^{+}$at $-10 \mathrm{mV}$, in $20 \mathrm{mM} \mathrm{Na}^{+}$at $-80 \mathrm{mV}$, or in $10 \mathrm{~mm} \mathrm{Na}$ at $-90 \mathrm{mV}$, AMPA- and kainate-induced current amplitudes were reduced to $<1.3 \mathrm{nA}$, so that with an effective series resistance of $<7 \mathrm{M} \Omega$, the resulting voltage error was $<10 \mathrm{mV}$. As in the recordings from patches, all extracellular solutions were supplemented with MK-801 (10 $\mu \mathrm{M})$, tetrodotoxin $(0.5 \mu \mathrm{M})$, and $\mathrm{Cd}^{2+}(100 \mu \mathrm{M})$ to block NMDA receptors, voltagegated $\mathrm{Na}^{+}$channels, and $\mathrm{Ca}^{2+}$ channels, respectively.

The membrane surface area of a neuron was estimated from the measurement of whole-cell capacitance. First, the residual uncompensated pipette capacitance was calculated from the capacitative current transient during a $10 \mathrm{mV}$ voltage step in the cell-attached mode after formation of a G $\Omega$ seal; the residual pipette capacitance was $2.8 \pm 0.1 \mathrm{pF}(n=155)$. The whole-cell capacitance was then calculated from the capacitative transient during a $10 \mathrm{mV}$ voltage step in the whole-cell mode, after subtraction of the residual pipette capacitance.

\section{Toxicity experiments}

Prolonged $\left(24 \mathrm{hr}\right.$ ) exposures to kainate were performed in a $6 \% \mathrm{CO}_{2}$ incubator at $37^{\circ} \mathrm{C}$, using an exposure medium of L15 supplemented with glucose $(3.6 \mathrm{mg} / \mathrm{ml})$ and sodium bicarbonate $(0.15 \%$, w/v), as described previously (Vandenberghe et al., 2000). Brief (10 min) exposures to kainate were performed in room air at $37^{\circ} \mathrm{C}$, using an extracellular solution with the following composition (in $\mathrm{mM}$ ): $133 \mathrm{NaCl}, 3 \mathrm{KCl}, 10 \mathrm{CaCl}_{2}, 1$ $\mathrm{MgCl}_{2}, 10$ HEPES, 15 glucose, and $10 \mathrm{mg} / \mathrm{ml}$ phenol red. After brief exposures, cultures were washed twice with agonist-free exposure solution and returned to the $37^{\circ} \mathrm{C}, 6 \% \mathrm{CO}_{2}$ incubator in the initial, complete culture medium. The NMDA receptor antagonist MK-801 $(10 \mu \mathrm{M})$ was added during all kainate exposures.

Neuronal survival was quantified, as described previously in detail (Vandenberghe et al., 2000), by morphological examination of neurons under phase-contrast optics immediately before exposure and again $24 \mathrm{hr}$ later, followed by immunostaining for the motoneuron marker peripherin.

\section{Data analysis}

All values and all error bars in figures denote mean \pm SEM, unless indicated otherwise. Statistical analyses were performed with SigmaStat (SSPS, Chicago, IL). Statistical significance of differences was analyzed with two-tailed Student's $t$ test for comparison between two groups with equal variances, with Mann-Whitney rank sum test for comparison be- 

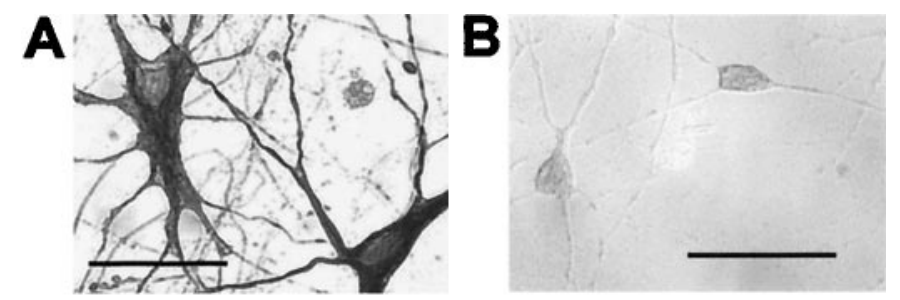

Figure 1. Motoneurons and dorsal horn neurons in culture. A, Immunostaining of motoneuron-enriched culture for the motoneuron marker peripherin on day 10 in vitro. $B$, Lack of peripherin immunostaining in dorsa horn neurons on day 10 in vitro. In these cultures, motoneurons and dorsal horn neurons reach a high degree of morphological differentiation. Shown are Nomarski differential interference optics images. Scale bars, $50 \mu \mathrm{m}$.

tween two groups with unequal variances, and with one-way ANOVA and Student-Newman-Keuls test for comparison between more than two groups with equal variances. Differences were considered significant at $p<$ 0.05 .

Measurements of peak and steady-state amplitudes and kinetics were based on the average of 3-10 agonist-evoked responses. Decay time constants and rates of onset of desensitization of peak responses recorded from patches were fitted with one or the sum of two exponentials using a Chebyshev (pCLAMP) fitting algorithm. Dose-response curves were fitted to the Hill equation $I=I_{\max } /\left(1+\left(\mathrm{EC}_{50} /[\text { agonist] })^{n}\right)\right.$, where [agonist] is the agonist concentration, $I$ is the current produced by [agonist], $I_{\max }$ is the maximum current at infinite [agonist], $\mathrm{EC}_{50}$ is the agonist concentration producing $50 \%$ of $\mathrm{I}_{\max }$, and $n$ is the Hill coefficient.

\section{Materials}

Cloned cDNA for the flip and flop forms of the four AMPA receptor subunits were gifts from Dr. Stephen Heinemann (The Salk Institute, San Diego, CA) and Dr. Peter Seeburg (Max-Planck-Institute for Medical Research, Heidelberg, Germany). All restriction enzymes were purchased from New England Biolabs (Beverly, MA). GYKI 53655 and cyclothiazide were gifts from Eli Lilly (Indianapolis, IN). AMPA was purchased from Tocris Cookson (Ballwin, MO) as the active enantiomer $S$-AMPA. MK 801 was also obtained from Tocris Cookson. SYBR Green-1 and tetrodotoxin were purchased from Molecular Probes (Eugene, OR). Other chemicals were obtained from Sigma.

\section{RESULTS}

A motoneuron-enriched neuronal population from rat ventral spinal cord was cultured on a feeder layer of spinal astrocytes. Between 80 and $90 \%$ of neurons in these cultures are motoneurons, as determined by immunostaining for the motoneuron markers peripherin and SMI-32 (Fig. 1) (Vandenberghe et al., 2000). For single-cell experiments, motoneurons were identified according to previously defined morphological criteria (Vandenberghe et al., 2000). In this study, we compared motoneurons with rat dorsal horn neurons grown in the same culture conditions.

\section{Expression of the flip and flop isoforms of the AMPA receptor subunits in motoneurons and dorsal horn neurons}

The desensitization properties of AMPA receptors are affected by multiple molecular determinants, in particular by subunit composition and alternative splicing of the flip/flop region of the receptor subunits (Sommer et al., 1990; Mosbacher et al., 1994; Partin et al., 1994; Geiger et al., 1995; Koike et al., 2000). AMPA receptors consisting of subunits in the flip isoform desensitize more slowly and less completely than receptors composed of flop subunits. We have previously quantified the relative abundance of the four AMPA receptor subunits in spinal motoneurons and found no major difference in average AMPA receptor subunit expression pattern between this cell type and dorsal horn neurons (Vandenberghe et al., 2000). Several groups have used in situ hybridization to qualitatively assess the expression of the flip and flop splice variants in spinal motoneurons, with results ranging from preferential flip isoform expression (Tölle et al., 1993; Jakowec et al., $1995)$ to predominant flop isoform expression (Tomiyama et al., 1996).

We have previously described an RT-PCR method that allows reliable quantification of the relative abundance of the mRNAs of
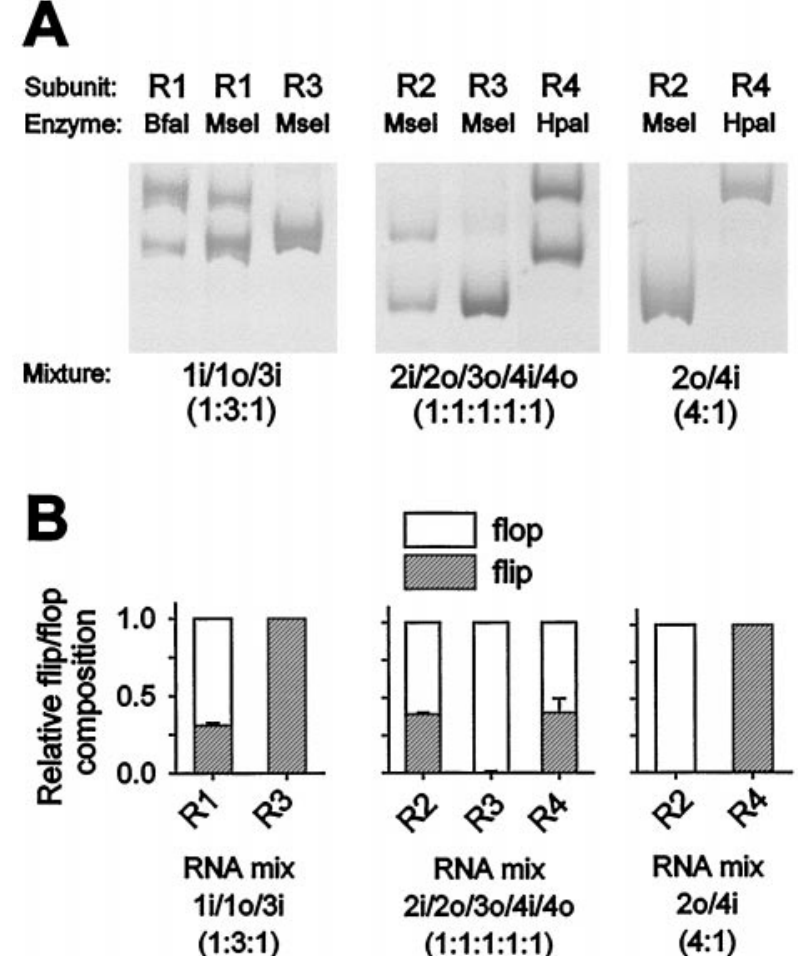

Figure 2. Validation of quantification of relative abundance of flip and flop splice variants by RT-PCR. Three control mixtures of RNAs transcribed from cDNA clones of the AMPA receptor subunits were designed to span the set of two splice variants of each of the four subunits. The composition of the mixtures is designated by shorthand representation of AMPA subunits ( $1 i$ for GluR1 flip, $2 o$ for GluR2 flop, and so forth). The RT-PCR protocol was applied to $\sim 0.004$ fmol RNA copies of each mixture to test whether ratios of flip and flop splice variants were maintained during RT-PCR. In a first step, the relative abundance of each of the four subunits was determined by first-round PCR and digestion with four subunit-specific restriction enzymes (Vandenberghe et al., 2000). Next, the relative abundance of the flip and flop splice variants of each AMPA receptor subunit was quantified by second-round, subunit-specific PCR, followed by digestion of second-round PCR products with restriction enzymes that distinguish the two splice variants of each subunit (see Materials and Methods). The digestion products were visualized on $5 \%$ polyacrylamide gels by digital fluorimetric scanning. $A$, Products of second-round PCR using primers specific for the subunit indicated above each lane were digested with the indicated restriction enzymes (see Materials and Methods for the length of the different digestion fragments). The RNA mixture is indicated below each gel. $B$, Quantification of the relative flip/flop composition of each subunit present in the control RNA mixtures by RT-PCR and restriction digestion (mean $\pm \mathrm{SD} ; n=3$ for each mix). The RNA mixture is indicated below each graph.

the flip and flop splice variants in single neurons (Brorson et al., 1999). For the present study, additional control experiments were performed, confirming the ability of this protocol to quantify the fractional expression of the flip and flop isoforms of each AMPA receptor subunit (Fig. 2).

Using this single-cell RT-PCR assay, we determined the relative abundance of the flip and flop splice variants of each of the four AMPA receptor subunits in 11 motoneurons and 13 dorsal horn neurons (Fig. 3). Most of these neurons (10 motoneurons and 11 dorsal horn neurons) were included in the previously published analysis of relative abundance of the four AMPA receptor subunits (Vandenberghe et al., 2000). In motoneurons, the flip and flop isoforms were approximately equally abundant for the subunits GluR1, GluR3, and GluR4, whereas GluR2 was expressed predominantly in the flop isoform (Fig. 3). Of all eight AMPA receptor subunit mRNA species in motoneurons, GluR2 flop was by far the most heavily expressed, accounting for approximately one-third of total AMPA receptor subunit mRNA. No significant differences in the flip/flop ratios of the four AMPA receptor subunits were found between motoneurons and dorsal horn neurons (Fig. 3). 
A

subunit: R1 R1 R2 R3 R4 enzyme: Bfal Msel Msel Msel Hpal

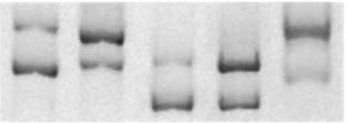

B

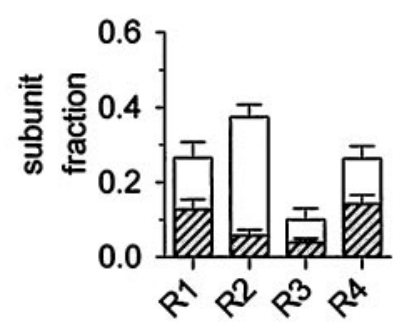

dorsal horn neuron R1 R1 R2 R4 Bfal Msel Msel Hpal

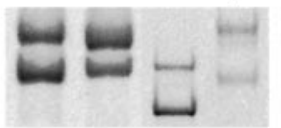

dorsal horn neurons

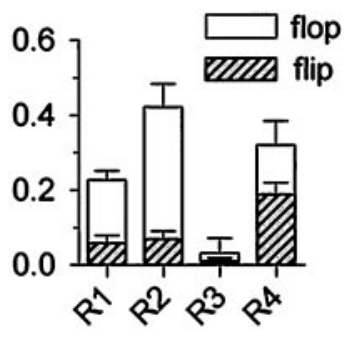

Figure 3. Flip/flop alternative splicing pattern of AMPA receptor subunits in motoneurons and dorsal horn neurons. $A$, Fractional expression of flip and flop splice variants of AMPA receptor subunits in one motoneuron (left) and one dorsal horn neuron (right). Second-round PCR products specific for the subunit indicated above each lane were digested with the indicated restriction enzymes that distinguish the flip and flop splice variants of each subunit (see Materials and Methods for the length of the different digestion fragments). The digestion fragments were separated on $5 \%$ polyacrylamide gels and visualized by digital fluorimetric scanning. The dorsal horn neuron shown did not express GluR3 at detectable levels. $B$, Summary of fractional subunit and flip/flop splice variant expression in motoneurons (left $n=11)$ and dorsal horn neurons (right; $n=13)$. There were no significant differences in relative abundance of the flip/flop splice variants between the two cell groups. Most of these neurons were included in the previously published description of relative abundance of the four AMPA receptor subunits (Vandenberghe et al., 2000). The additional cells ( 1 motoneuron and 2 dorsal horn neurons) did not alter the previous conclusion that no significant difference in relative abundance of GluR1-4 existed between the two cell populations.

\section{Desensitization characteristics of AMPA receptors in motoneurons and dorsal horn neurons}

The similar expression profiles of AMPA receptor subunit mRNAs and their flip/flop splice variants in motoneurons and dorsal horn neurons suggest that AMPA receptors in the two cell populations may have similar desensitization properties. However, mRNA expression does not necessarily reflect protein expression and assembly of subunits into functional receptors. We therefore performed patch-clamp electrophysiological experiments to provide a direct, functional assessment of AMPA receptor desensitization properties in the two cell groups.

The kinetics of AMPA receptor desensitization in motoneurons and dorsal horn neurons were studied using fast application of the physiological AMPA receptor agonist glutamate to nucleated (Sather et al., 1992; Patneau et al., 1993) and conventional (Hamill et al., 1981) outside-out membrane patches isolated from neuronal somata. Glutamate-induced currents were recorded in the presence of MK-801 $(10 \mu \mathrm{M})$ to block NMDA receptors. To determine whether kainate receptors contributed to the observed glutamate responses, currents were recorded in both the absence and presence of lanthanum $(10 \mu \mathrm{M})$, an inhibitor of kainate receptors (Huettner et al., 1998; Li et al., 1999). Lanthanum did not produce any significant change in amplitude or time course of glutamateinduced currents, indicating that kainate receptors did not contribute to the observed responses $(n=11$ motoneuron patches and 11 dorsal horn neuron patches; data not shown).

AMPA receptor desensitization kinetics were measured in 12 nucleated and two conventional outside-out patches from motoneurons. AMPA receptor kinetics were similar in both patch configurations. As illustrated in Figure $4 A$, patches from motoneurons responded to $100 \mathrm{msec}$ pulses of $3 \mathrm{~mm}$ glutamate with a current that rose rapidly to a peak and showed rapid desensitization. The time course of desensitization was best fitted by the sum of two exponentials, of time constants $\tau_{\text {fast }}=3.41 \pm 0.84 \mathrm{msec}$ and $\tau_{\text {slow }}=13.90 \pm 1.15 \mathrm{msec}$, with a relative amplitude of the fast component of $75.0 \pm 2.9 \%$. The desensitization of AMPA receptors was extensive, with only $2.3 \pm 0.5 \%$ of the peak current remaining at the end of the pulse.

We also studied AMPA receptor deactivation, defined as the current decay after rapid removal of glutamate, in membrane patches from 11 motoneurons. In all patches, AMPA receptor currents deactivated rapidly after a $1 \mathrm{msec}$ pulse of $3 \mathrm{~mm}$ glutamate (Fig. $4 B$ ). The time course of current deactivation was well fitted by a single-exponential function with a time constant $(\tau)$ of $1.06 \pm$ 0.05 msec.

AMPA receptor desensitization and deactivation kinetics were also measured in somatic membrane patches (eight nucleated patches and six conventional outside-out patches) from dorsal horn neurons. AMPA receptor kinetics were again similar in both patch configurations. As in motoneuron patches, fast application of $3 \mathrm{~mm}$ glutamate for $100 \mathrm{msec}$ produced rapid and extensive desensitization in all dorsal horn neuron patches studied (Fig. 4A). A doubleexponential function again provided a better fit to the desensitization time course than a single exponential, with $\tau_{\text {fast }}=3.48 \pm 0.23$ $\operatorname{msec}(70.0 \pm 2.9 \%$ of fitted amplitude $)$ and $\tau_{\text {slow }}=12.9 \pm 1.36$ msec. Steady-state current amplitude was $2.2 \pm 0.3 \%$ of the peak amplitude. As in motoneurons, AMPA receptor deactivation was fast and best fitted with a single exponential, with $\tau=1.30 \pm 0.10$ msec $(n=9)$ (Fig. $4 B)$. None of the desensitization or deactivation parameters measured in dorsal horn neurons were significantly different from those in motoneurons.

The electrophysiological results described above reflect the properties of somatic AMPA receptors. However, somatic AMPA receptors may theoretically have different desensitization characteristics than dendritic AMPA receptors. To assess the desensitization properties of AMPA receptors in dendritic as well as somatic compartments, we also performed whole-cell electrophysiological experiments in motoneurons and dorsal horn neurons. Because of the extensive dendritic arborization of the neurons, agonist application in the whole-cell mode was not fast enough to allow accurate measurements of AMPA receptor-mediated peak currents and of the kinetics of AMPA receptor desensitization. However, the degree of desensitization can be estimated indirectly in whole-cell experiments by comparing the amplitude of the steady-state currents elicited by saturating concentrations of a strongly desensitizing AMPA receptor agonist (such as AMPA or glutamate) and a weakly desensitizing AMPA receptor agonist (such as kainate) (Sommer et al., 1990; Patneau et al., 1993; Partin et al., 1994). The reported affinities of AMPA receptors for AMPA and kainate vary considerably between neuronal cell types; for example, the $\mathrm{EC}_{50}$ of kainate at AMPA receptors ranges from $80 \mu \mathrm{M}$ in chick spinal motoneurons (O'Brien and Fischbach, 1986) to $>400 \mu \mathrm{M}$ in neurons of the chick cochlear nucleus (Raman and Trussell, 1992). To establish which concentrations of AMPA and kainate were saturating both in motoneurons and dorsal horn neurons, we measured concentration-response curves for both agonists in the two cell groups (Fig. 5). Concentration-response analysis demonstrated that there was no significant difference in apparent agonist affinity between motoneurons and dorsal horn neurons, and that $100 \mu \mathrm{M}$ AMPA and $1 \mathrm{~mm}$ kainate were virtually saturating concentrations in both cell populations (Fig. 5). The specific AMPA receptor antagonist GYKI $53655(50 \mu \mathrm{M})$ completely blocked the currents evoked by $100 \mu \mathrm{M}$ AMPA $(n=4$ motoneurons and 3 dorsal horn neurons) and by $1 \mathrm{~mm} \mathrm{KA}$ ( $n=4$ motoneurons and 4 dorsal horn neurons), indicating that these currents were AMPA receptormediated (data not shown).

The ratio of the steady-state current evoked by $100 \mu \mathrm{M}$ AMPA to the steady-state current evoked by $1 \mathrm{~mm}$ kainate $\left(I_{\mathrm{AMPA}} / I_{\mathrm{KA}}\right)$ was determined in 10 motoneurons and nine dorsal horn neurons, in $145 \mathrm{~mm}$ extracellular $\mathrm{Na}^{+}$at a holding potential of $-10 \mathrm{mV}$ (Fig. $6)$. There was no significant difference in $I_{\mathrm{AMPA}} / I_{\mathrm{KA}}$ between the 

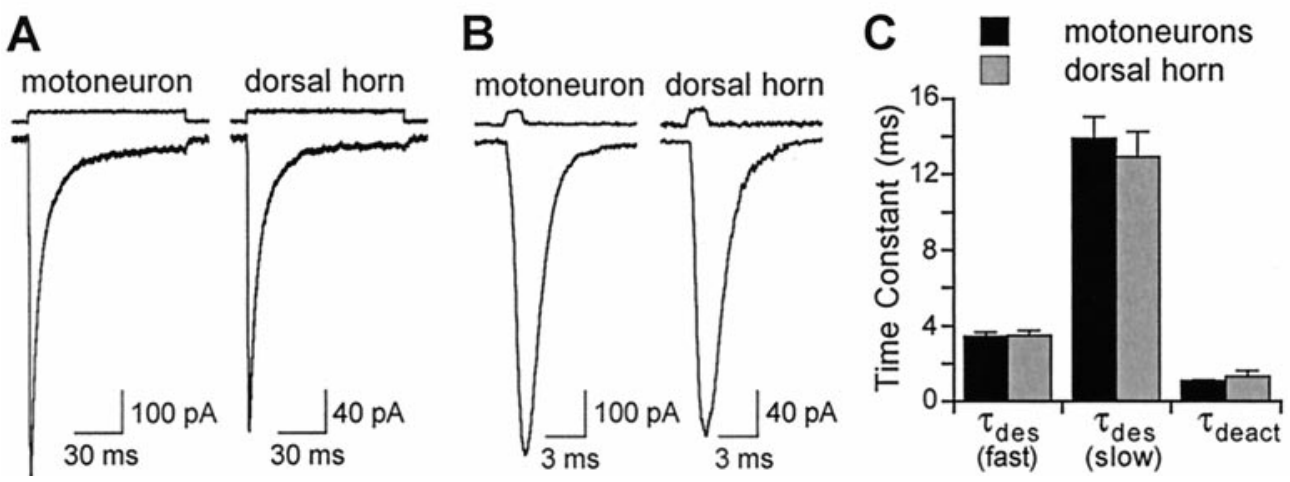

Figure 4. Desensitization and deactivation kinetics of AMPA receptors in motoneurons and dorsal horn neurons. $A, B$, Examples of responses evoked by $100 \mathrm{msec}(A)$ and $1 \mathrm{msec}(B)$ applications of $3 \mathrm{~mm}$ glutamate to nucleated macropatches from a motoneuron and a dorsal horn neuron, in $145 \mathrm{~mm} \mathrm{Na}^{+}$ at $-60 \mathrm{mV}$. The time of agonist application is indicated above each current trace by the junction potential trace recorded after disrupting the patch after recording (see Materials and Methods). $C$, The bar graph shows the mean time constants determined from exponential fits to data as illustrated in $A$ and $B$. Desensitization kinetics were measured by fitting the decay of responses to $100 \mathrm{msec}$ glutamate applications with the sum of two exponentials $(n=14$ motoneurons and 14 dorsal horn neurons); $\tau_{\text {des }}$ (fast) and $\tau_{\text {des }}$ (slow) are the time constants of the fast and slow components of desensitization, respectively. Deactivation kinetics were determined from the decay of the response to a $1 \mathrm{msec}$ application of glutamate fitted with a single exponential with time constant $\tau_{\text {deact }}(n=11$ motoneurons and 9 dorsal horn neurons). There were no significant differences in the time constants of desensitization and deactivation between the two cell groups.

two cell populations: $I_{\mathrm{AMPA}} / I_{\mathrm{KA}}$ was $0.22 \pm 0.03$ in motoneurons and $0.29 \pm 0.09$ in dorsal horn neurons.

We further compared the degree of AMPA receptor desensitization between motoneurons and dorsal horn neurons in the whole-cell mode by studying the effect of cyclothiazide, a compound that allosterically inhibits AMPA receptor desensitization (Patneau et al., 1993; Yamada and Tang, 1993). In particular, we measured the ratio of peak current evoked by $100 \mu \mathrm{M}$ AMPA in the presence of $100 \mu \mathrm{M}$ cyclothiazide to the steady-state current evoked by $100 \mu \mathrm{M}$ AMPA alone. In the presence of cyclothiazide, the decay of responses to AMPA is sufficiently slow to allow resolution of the peak response in the whole-cell mode (Partin et al., 1994). The ratio of peak current evoked by AMPA in the presence of cyclothiazide to the steady-state current evoked by AMPA alone was $6.31 \pm 1.18$ in motoneurons $(n=10)$ and $8.45 \pm 1.63$ in dorsal horn neurons $(n=9)$; this difference was not significant $(p=0.44)$.

To also measure agonist-evoked currents at more negative membrane potentials, $I_{\mathrm{AMPA}} / I_{\mathrm{KA}}$ ratios and the effect of cyclothiazide were measured at $-90 \mathrm{mV}$ in $10 \mathrm{~mm}$ extracellular $\mathrm{Na}^{+}$, but again showed no significant difference between the two cell groups (data not shown).

Taken together, these electrophysiological results demonstrate that motoneurons and dorsal horn neurons do not differ from each other in the desensitization and deactivation properties of their AMPA receptors.

\section{AMPA receptor current density in motoneurons and dorsal horn neurons}

To assess the density of functional AMPA receptors in the membranes of motoneurons and dorsal horn neurons, we recorded the cell capacitance of each neuron included in the analysis of wholecell AMPA receptor-mediated currents described above. The capacitance of a cell is directly proportional to the surface area of its cell membrane (Hille, 1984); the amplitude of AMPA receptormediated current, on the other hand, relates to the total number of functional AMPA receptors. Therefore, AMPA receptor current density (defined as AMPA receptor-mediated current divided by capacitance) provides an estimate of functional AMPA receptor density.

Amplitudes of whole-cell currents evoked by AMPA receptor agonists were dramatically larger in motoneurons than in dorsal horn neurons. For example, the steady-state current evoked by 3 $\mathrm{mm}$ kainate in $10 \mathrm{~mm}$ extracellular $\mathrm{Na}^{+}$at $-90 \mathrm{mV}$ was $765.9 \pm 91$ pA in motoneurons $(n=12)$ compared with $72.8 \pm 17.8 \mathrm{pA}$ in dorsal horn neurons $(n=12)$ (see also current traces in Figs. 5, 6). This consistent, highly significant difference in AMPA receptor- mediated current amplitude between the two neuronal populations was considerably greater than could be explained by the larger membrane surface area of motoneurons, as estimated from capacitance measurements. Whole-cell capacitance typically ranged from 60 to $140 \mathrm{pF}$ in motoneurons and from 15 to $45 \mathrm{pF}$ in dorsal horn neurons. On average, the whole-cell capacitance of motoneurons $(95.3 \pm 3.0 \mathrm{pF} ; n=74)$ was approximately threefold larger than that of dorsal horn neurons $(28.5 \pm 1.0 \mathrm{pF} ; n=74)$. As a result, despite a considerable variation in AMPA receptor current density within each cell population (Fig. $7 A$ ), mean AMPA receptor current density was $\sim 2.5$-fold higher in motoneurons than in dorsal horn neurons (Fig. $7 B-D$ ). This striking difference in AMPA receptor current density between the two cell groups was observed with both AMPA and KA as agonists, was detected over the full range of the agonist concentration-response curves, and was independent of holding potential or composition of the extracellular solution (Fig. $7 B-D$ ).

\section{AMPA receptor current density is a determinant of selective motoneuron vulnerability}

We next performed toxicity experiments to determine to what extent the $\sim 2.5$-fold difference in AMPA receptor current density between motoneurons and dorsal horn neurons could explain their differential vulnerability to AMPA receptor agonists. As reported previously (Vandenberghe et al., 2000), $24 \mathrm{hr}$ exposure to $100 \mu \mathrm{M}$ kainate was considerably more toxic to motoneurons than to dorsal horn neurons (Fig. 8A). We asked whether motoneurons would still be more vulnerable to kainate than dorsal horn neurons if their AMPA receptor current density was reduced to the same average level as in dorsal horn neurons. We used two different pharmacological approaches to achieve a $\sim 2.5$-fold reduction of AMPA receptor current density in motoneurons. First, we used GYKI 53655, a noncompetitive AMPA receptor antagonist with an $\mathrm{IC}_{50}$ between 1 and $1.5 \mu \mathrm{M}$ (Bleakman et al., 1996). In whole-cell electrophysiological experiments, $1.5 \mu \mathrm{M}$ of GYKI 53655 reduced kainate-induced current density in motoneurons to $41.7 \pm 3.13 \%$ of its control value ( $n=4$ motoneurons). Second, kainate concentration-response analysis (Figs. 5A, 7C) indicated that $30 \mu \mathrm{M}$ kainate induced approximately the same current density in motoneurons as did $100 \mu \mathrm{M}$ kainate in dorsal horn neurons. Interestingly, when these treatments were applied, the toxicity induced by $24 \mathrm{hr}$ exposure of motoneurons to either $100 \mu \mathrm{m}$ kainate with 1.5 $\mu \mathrm{M}$ GYKI 53655 or $30 \mu \mathrm{M}$ kainate was very similar to the toxicity induced by $24 \mathrm{hr}$ exposure of dorsal horn neurons to $100 \mu \mathrm{M}$ kainate alone (Fig. 8A). GYKI $53655(1.5 \mu \mathrm{M})$ alone had no significant effect on motoneuron survival $(n=3)$ (data not shown). 

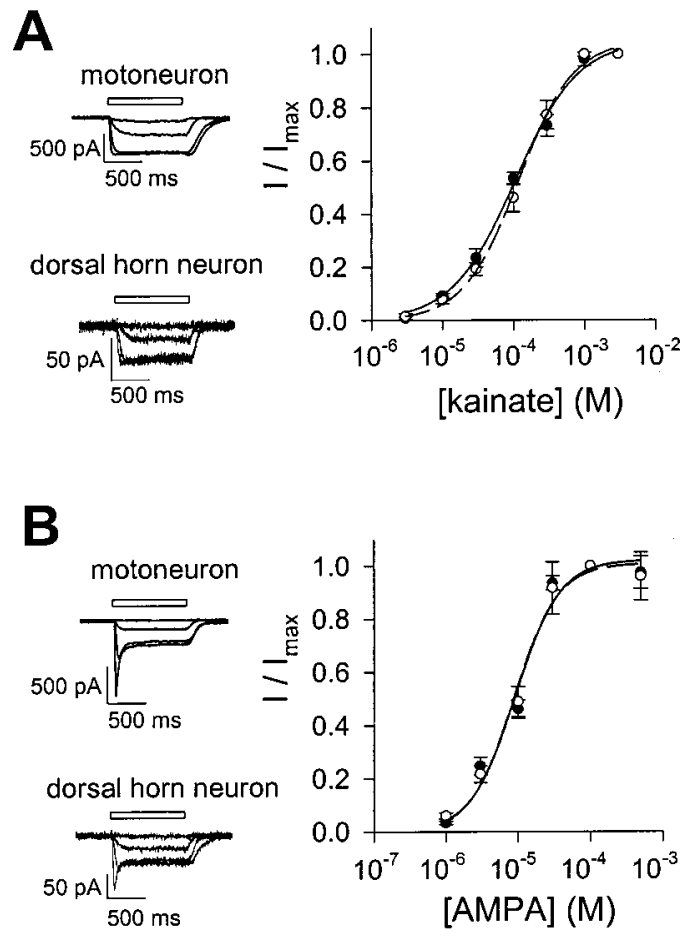

Figure 5. Concentration-response relation for kainate- and AMPAinduced currents in motoneurons and dorsal horn neurons. $A$, Concentration-response relation for kainate-induced whole-cell steady-state currents in motoneurons $(\mathbf{O})$ and dorsal horn neurons $(\bigcirc)$. Currents were recorded in $10 \mathrm{mM}$ extracellular $\mathrm{Na}^{+}$at $-90 \mathrm{mV}$, in response to kainate concentrations ranging from $3 \mu \mathrm{M}$ to $3 \mathrm{~mm}$, and were normalized to the responses obtained at $3 \mathrm{~mm}$. Each point represents mean $\pm \mathrm{SEM}$ of data from six cells. The Hill equation (see Materials and Methods) was used to fit the data from motoneurons (solid curve) and dorsal horn neurons (dashed curve). $\mathrm{EC}_{50}$ values estimated from fits to pooled data were $106.7 \mu \mathrm{M}$ for motoneurons and $119.6 \mu \mathrm{M}$ for dorsal horn neurons, with Hill coefficients of 0.98 and 1.12 , respectively. Insets show current traces evoked by $10 \mu \mathrm{M}, 100$ $\mu \mathrm{M}, 1 \mathrm{mM}$, and $3 \mathrm{~mm}$ kainate in a motoneuron (with whole-cell capacitance of $81.3 \mathrm{pF}$ ) and a dorsal horn neuron (with whole-cell capacitance of 20.3 $\mathrm{pF})$. $B$, Concentration-response relation for AMPA-induced whole-cell steady-state currents in motoneurons $(O)$ and dorsal horn neurons $(O)$. Currents were recorded in $20 \mathrm{~mm}$ extracellular $\mathrm{Na}^{+}$at $-80 \mathrm{mV}$, in response to AMPA concentrations ranging from 1 to $500 \mu \mathrm{M}$, and were normalized to the responses at $100 \mu \mathrm{M}$. Each point represents mean \pm SEM from six to eight cells. Solid and dashed curves represent fits to pooled data from motoneurons and dorsal horn neurons, respectively. $\mathrm{EC}_{50}$ values were $9.2 \mu \mathrm{M}$ for motoneurons and $8.9 \mu \mathrm{M}$ for dorsal horn neurons, with Hill coefficients of 1.40 and 1.44 , respectively. Insets show current traces evoked by $1,10,100$, and $500 \mu \mathrm{M}$ AMPA in a motoneuron (with whole-cell capacitance of $61.7 \mathrm{pF}$ ) and a dorsal horn neuron (with whole-cell capacitance of $36.1 \mathrm{pF}$ ).

These data suggest that AMPA receptor current density may account for much of the differential vulnerability of motoneurons and dorsal horn neurons to AMPA receptor agonists.

It has recently been reported that AMPA receptor activation can trigger removal of AMPA receptors from the plasma membrane by ligand-induced endocytosis (Carroll et al., 1999). If this phenomenon occurred to a different degree in motoneurons than in dorsal horn neurons, the difference in AMPA receptor current density observed at the beginning of the $24 \mathrm{hr}$ kainate exposure would not be representative of the difference in current density during the rest of the exposure; this could confound the interpretation of the toxicity experiments described above. To minimize the chance of major changes in AMPA receptor surface expression during agonist exposure, we also studied toxicity resulting from brief (10 $\mathrm{min})$ kainate exposures. Brief exposure of motoneurons and dorsal horn neurons to $1 \mathrm{~mm}$ kainate in $2 \mathrm{~mm}$ extracellular $\mathrm{Ca}^{2+}$ produced little or no cell death (data not shown). However, raising extracellular $\mathrm{Ca}^{2+}$ from 2 to $10 \mathrm{~mm}$ markedly enhanced kainate toxicity, as reported previously (Carriedo et al., 1996, 2000; Van Den Bosch et
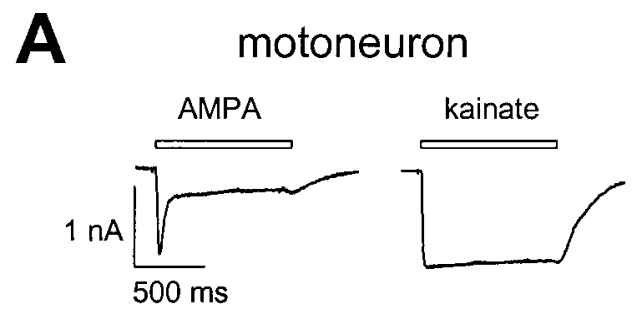

B dorsal horn neuron

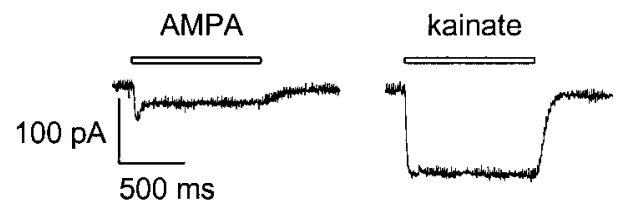

Figure 6. AMPA- and kainate-induced whole-cell currents in motoneurons and dorsal horn neurons. Whole-cell currents evoked by $100 \mu \mathrm{M}$ AMPA and $1 \mathrm{~mm}$ kainate were recorded in $145 \mathrm{~mm}$ extracellular $\mathrm{Na}^{+}{ }^{+}$at $-10 \mathrm{mV}$ in a motoneuron $(A)$ and a dorsal horn neuron $(B)$. The motoneuron shown in $A$ and the dorsal horn neuron shown in $B$ had whole-cell capacitances of 121.2 and $37.1 \mathrm{pF}$, respectively.

al., 2000). Therefore, the toxicity experiments shown in Figure $8 B$ were performed in $10 \mathrm{~mm}$ extracellular $\mathrm{Ca}^{2+}$. Motoneurons were clearly more vulnerable than dorsal horn neurons to brief exposure to $1 \mathrm{~mm}$ kainate (Fig. $8 \mathrm{~B}$ ). As in the $24 \mathrm{hr}$ exposures, this difference in vulnerability to kainate between the two cell populations was essentially eliminated by pharmacological reduction of AMPA receptor current density in motoneurons to the same average level as in dorsal horn neurons (Fig. 8B).

\section{DISCUSSION}

Motoneurons are more susceptible to AMPA receptor-mediated death than other spinal neurons (Hugon et al., 1989; Rothstein et al., 1993; Carriedo et al., 1996, 2000; Ikonomidou et al., 1996; Bar-Peled et al., 1999; Vandenberghe et al., 2000); this observation was confirmed in the present study. Comparing spinal motoneurons with other spinal neurons appears to be more relevant to ALS than comparing them with neurons from nonspinal regions, because the primary pathogenic abnormalities underlying ALS may be regionally restricted. For example, the glial glutamate transporter defect that may be involved in the pathogenesis of a subset of ALS cases was detected in spinal cord and motor cortex but not in other CNS regions such as cerebellum or hippocampus (Rothstein et al., 1995). We and others have shown previously that motoneurons express AMPA receptors with intermediate whole-cell relative $\mathrm{Ca}^{2+}$ permeability (Greig et al., 2000; Vandenberghe et al., 2000). However, this property does not distinguish them from spinal dorsal horn neurons and therefore is not sufficient to account for their selective vulnerability (Vandenberghe et al., 2000). The aim of the present study was to determine whether the difference in vulnerability between motoneurons and other spinal neurons can be explained by a difference in AMPA receptor desensitization and/or a difference in density of functional AMPA receptors.

\section{AMPA receptor desensitization and selective motoneuron vulnerability}

This study provides the first quantitative analysis of the desensitization and deactivation properties of the AMPA receptors of mammalian spinal motoneurons. AMPA receptors in motoneurons consistently exhibited fast deactivation and rapid, extensive desensitization. AMPA receptor desensitization kinetics in rat motoneurons were similar to those previously measured in chick spinal motoneurons (Smith et al., 1991). Deactivation and desensitization kinetics of AMPA receptors in motoneurons also resembled AMPA receptor kinetics in cerebellar Purkinje neurons (Raman et al., 1994; Häusser and Roth, 1997), were slower than AMPA 
A

motoneurons

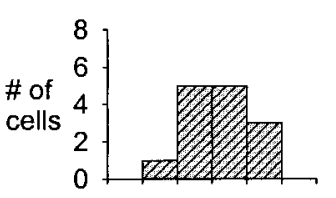

$0 \begin{array}{llllll}0 & 2 & 4 & 6 & 8 & 1012\end{array}$

Current density $(\mathrm{pA} / \mathrm{pF})$

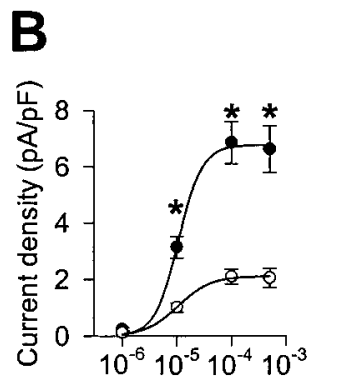

[AMPA] (M)

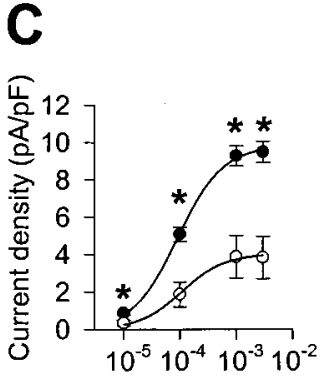

[kainate] (M)

$\mathbf{D}$

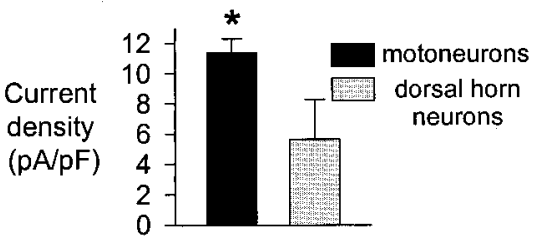

Figure 7. AMPA receptor current density in motoneurons and dorsal horn neurons. A, Histograms summarizing distributions of AMPA receptor current density in 14 motoneurons (left) and 13 dorsal horn neurons (right). Whole-cell currents induced by $100 \mu \mathrm{M}$ AMPA were recorded in $20 \mathrm{~mm}$ extracellular $\mathrm{Na}^{+}$at $-80 \mathrm{mV}$. B, Concentration-response curves for eight motoneurons $(\bullet)$ and seven dorsal horn neurons $(\bigcirc)$ constructed from measurements of whole-cell steady-state current densities in response to AMPA concentrations ranging from 1 to $500 \mu \mathrm{M}$ in $20 \mathrm{~mm}$ extracellular $\mathrm{Na}^{+}$at $-80 \mathrm{mV}$. $C$, Concentration-response curves for six motoneurons $(\bullet)$ and six dorsal horn neurons $(O)$ constructed from measurements of whole-cell steady-state current densities in response to kainate concentrations ranging from $10 \mu \mathrm{M}$ to $3 \mathrm{mM}$ in $10 \mathrm{~mm}$ extracellular $\mathrm{Na}^{+}$at $-90 \mathrm{mV}$. $D$, Whole-cell steady-state current density in 10 motoneurons and nine dorsal horn neurons in response to $1 \mathrm{~mm}$ kainate in $145 \mathrm{~mm}$ extracellular $\mathrm{Na}^{+}$at $-10 \mathrm{mV}$. In $B-D$, an asterisk indicates significant difference between the two cell populations.

receptor kinetics in brain stem auditory neurons (Raman and Trussell, 1992; Raman et al., 1994), and were considerably faster than in hippocampal and neocortical pyramidal neurons (Geiger et al., 1995; Spruston et al., 1995).

Because our analysis of AMPA receptor desensitzation was based on measurements from somatic membrane patches and on whole-cell recordings, we probably did not fully assess the desensitization characteristics of AMPA receptors expressed on distal dendrites. However, a major difference in desensitization between distal dendritic and more proximal AMPA receptors seems rather unlikely in the light of evidence that AMPA receptor desensitization in hippocampal neurons and Purkinje neurons does not differ significantly between somatic and distal dendritic patches (Spruston et al., 1995; Häusser and Roth, 1997).

Although the molecular control of AMPA receptor kinetics is complex and incompletely understood, subunit composition and flip/flop alternative splicing of subunits appear to be important determinants of AMPA receptor desensitization (Sommer et al., 1990; Mosbacher et al., 1994; Partin et al., 1994; Koike et al., 2000). We have previously quantified the relative abundance of the AMPA receptor subunits GluR1-4 in motoneurons by single-cell
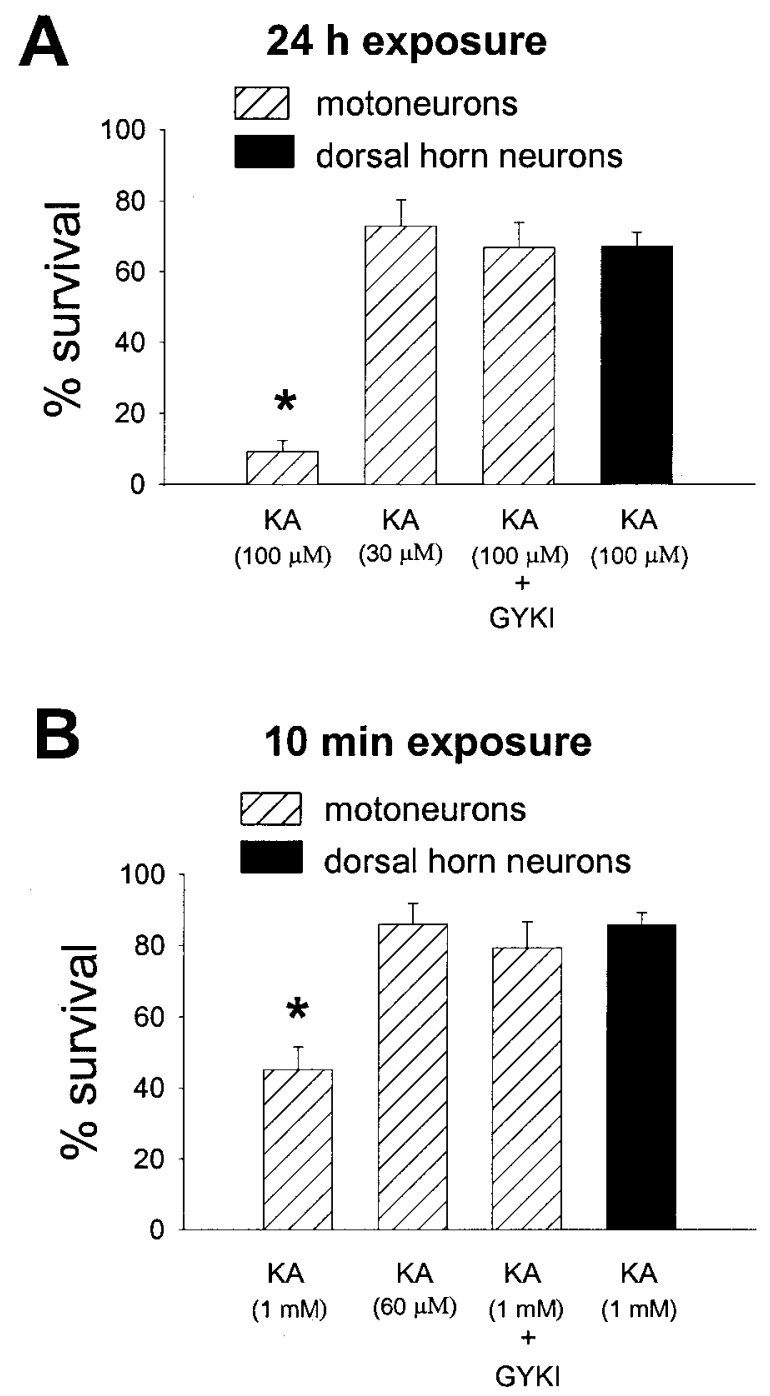

Figure 8. AMPA receptor current density is a determinant of the differential vulnerability of motoneurons and dorsal horn neurons to kainate. $A$, Motoneurons were exposed for $24 \mathrm{hr}$ to either $100 \mu \mathrm{M}$ kainate $(K A), 30 \mu \mathrm{M}$ kainate, or $100 \mu \mathrm{M}$ kainate $+1.5 \mu \mathrm{M}$ GYKI 53655; dorsal horn neurons were exposed for $24 \mathrm{hr}$ to $100 \mu \mathrm{M}$ kainate ( $n=3$ for each condition). MK-801 $(10 \mu \mathrm{M})$ was added during all agonist exposures. Kainate $(30 \mu \mathrm{M})$ and kainate $(100 \mu \mathrm{M})+$ GYKI $53655(1.5 \mu \mathrm{M})$ induce approximately the same average current density in motoneurons as does $100 \mu \mathrm{M}$ kainate in dorsal horn neurons (see Results). An asterisk indicates motoneuron survival significantly different from the dorsal horn neuron survival after exposure to $100 \mu \mathrm{M}$ kainate. $B$, Motoneurons were exposed for $10 \mathrm{~min}$ to either $1 \mathrm{~mm}$ kainate $(K A), 60 \mu \mathrm{m}$ kainate, or $1 \mathrm{~mm}$ kainate $+1.5 \mu \mathrm{M}$ GYKI 53655 ; dorsal horn neurons were exposed for $10 \mathrm{~min}$ to $1 \mathrm{~mm}$ kainate $(n=$ 3 for each condition). Cultures were exposed to agonist in the presence of $10 \mu \mathrm{M}$ M K-801 and $10 \mathrm{~mm}$ extracellular $\mathrm{Ca}^{2+}$. Kainate $(60 \mu \mathrm{M})$ and kainate $(1 \mathrm{mM})+$ GYKI $53655(1.5 \mu \mathrm{M})$ induce approximately the same average current density in motoneurons as does $1 \mathrm{~mm}$ kainate in dorsal horn neurons (see Results). An asterisk indicates motoneuron survival significantly different from the dorsal horn neuron survival after exposure to $1 \mathrm{~mm}$ kainate.

RT-PCR (Vandenberghe et al., 2000). In the present study, singlecell RT-PCR products were used to determine the relative proportion of the flip and flop splice variants of the AMPA receptor subunits in this cell type. Motoneurons were found to express mixed proportions of mRNAs for the flip and flop isoforms of each subunit. The flip/flop alternative splicing pattern of motoneurons is compatible with the desensitization characteristics of their AMPA receptors: AMPA receptor desensitization time constants and $I_{\mathrm{AMPA}} / I_{\mathrm{KA}}$ ratios measured in motoneurons were similar to those observed in host cells expressing mixtures of flip and flop splice variants (Sommer et al., 1990; Mosbacher et al., 1994; Partin et al., 1994). 
The desensitization and deactivation characteristics of AMPA receptors and flip/flop alternative splicing were also studied in dorsal horn neurons. However, dorsal horn neurons did not significantly differ from motoneurons in any of these parameters. The AMPA receptor desensitization time constants in dorsal horn neurons were consistent with earlier studies on spinal neurons from chick (Trussell and Fischbach, 1989).

These results lead to the conclusion that AMPA receptor desensitization cannot explain the differential vulnerability of motoneurons and dorsal horn neurons to AMPA receptor agonists.

\section{Functional AMPA receptor density and selective motoneuron vulnerability}

To assess the density of functional AMPA receptors in motoneurons and dorsal horn neurons, we measured the density of AMPA receptor-mediated current in neurons of both populations. We chose this approach for several reasons: AMPA receptor current density is a quantifiable parameter, it can be measured at the single-cell level, and it is directly proportional to functional AMPA receptor density and unaffected by the presence of nonfunctional AMPA receptor protein. The present study demonstrates that AMPA receptor current density is, on average, $\sim 2.5$-fold higher in motoneurons than in dorsal horn neurons. This remarkable difference between the two cell groups is in agreement with earlier, preliminary observations made under different ionic conditions (Vandenberghe et al., 2000).

It is important to note that current density is not determined by functional AMPA receptor density alone but is also determined by single-channel conductance and open probability of the receptors. Therefore, the observed difference in AMPA receptor current density between motoneurons and dorsal horn neurons might also result from differences in AMPA receptor single-channel conductance and/or open probability between the two cell groups. AMPA receptor single-channel conductance strongly depends on subunit composition: AMPA receptors lacking GluR2 in its $Q / R$ siteedited form exhibit a considerably higher conductance (Swanson et al., 1997). However, a major difference in AMPA receptor singlechannel conductance based on differential subunit composition is unlikely to exist between motoneurons and dorsal horn neurons, given our previous finding that the relative abundance of GluR2, the degree of $\mathrm{Q} / \mathrm{R}$ site editing of GluR2, and the whole-cell relative $\mathrm{Ca}^{2+}$ permeability of AMPA receptors are similar in the two cell populations (Vandenberghe et al., 2000). AMPA receptor open probability, on the other hand, is mainly determined by receptor desensitization. In addition, AMPA receptor singlechannel conductance and open probability can be modulated by AMPA receptor phosphorylation (Derkach et al., 1999; Banke et al., 2000). Changes in AMPA receptor phosphorylation have been implicated in long-term potentiation and long-term depression in hippocampal neurons (Swope et al., 1999). However, constitutive differences in the level of AMPA receptor phosphorylation between different neuronal cell types have not been reported. Therefore, the most parsimonious explanation for the observed difference in AMPA receptor current density between motoneurons and dorsal horn neurons appears to be that motoneurons express a greater density of functional AMPA receptors. It remains to be established whether the difference in whole-cell AMPA receptor current density between the two populations reflects a difference in synaptic or extrasynaptic AMPA receptors, or both.

Considerable evidence supports a link between glutamate receptor-mediated $\mathrm{Ca}^{2+}$ influx, intracellular $\mathrm{Ca}^{2+}$ accumulation, and subsequent neuronal death (Hartley et al., 1993; Lu et al., 1996). The difference in AMPA receptor current density between motoneurons and dorsal horn neurons, in the absence of a major difference in whole-cell relative $\mathrm{Ca}^{2+}$ permeability (Vandenberghe et al., 2000) or desensitization of AMPA receptors, predicts that, per unit of cell membrane area, glutamate will trigger a $\sim 2.5$-fold larger AMPA receptor-mediated $\mathrm{Ca}^{2+}$ influx in motoneurons than in dorsal horn neurons. How does this difference in AMPA receptor-mediated $\mathrm{Ca}^{2+}$ entry per cell surface area between the two cell populations translate into a comparison of cytoplasmic $\mathrm{Ca}^{2+}$ loads, distributed throughout the cell volume? To answer this question, one has to take into account the fact that motoneurons are larger cells than dorsal horn neurons and consequently have a smaller surface/volume ratio. If motoneurons and dorsal horn neurons were spherical, the following equation would apply: $\left(I_{\mathrm{MN}} / V_{\mathrm{MN}}\right) /\left(I_{\mathrm{DH}} / V_{\mathrm{DH}}\right)=\left[\left(I_{\mathrm{MN}} / A_{\mathrm{MN}}\right) /\left(I_{\mathrm{DH}} / A_{\mathrm{DH}}\right)\right] \cdot\left(A_{\mathrm{DH}} / A_{\mathrm{MN}}\right)^{1 / 2}$, where $I$ is AMPA receptor-mediated current, $V$ is cell volume, and $A$ is cell surface area of motoneurons (MN) and dorsal horn neurons $(\mathrm{DH})$. The whole-cell capacitance measurements indicate that $\left(A_{\mathrm{DH}} / A_{\mathrm{MN}}\right)$ is approximately one-third; the current density measurements indicate that $\left(I_{\mathrm{MN}} / A_{\mathrm{MN}}\right) /\left(I_{\mathrm{DH}} / A_{\mathrm{DH}}\right)$ is $\sim 2.5$. Then, according to the above equation, $\left(I_{\mathrm{MN}} / V_{\mathrm{MN}}\right) /\left(I_{\mathrm{DH}} / V_{\mathrm{DH}}\right)$ would equal $\sim 1.44$. Thus, even under the simplifying assumption of spherical neuronal geometry, the $\sim 2.5$-fold larger AMPA receptor current density in motoneurons would, during AMPA receptor activation, lead to a nearly $50 \%$ larger $\mathrm{Ca}^{2+}$ load per cell volume. In dendritic regions, the difference in surface/volume ratio between motoneurons and dorsal horn neurons is likely to be considerably smaller than predicted from a spherical model, producing even greater volumetric $\mathrm{Ca}^{2+}$ loads in motoneurons compared with dorsal horn neurons. In addition, recent functional studies indicate that the $\mathrm{Ca}^{2+}$ buffering capacities of spinal motoneurons are poor compared with those of other, less vulnerable neuronal cell types (Palecek et al., 1999). The large AMPA receptor-mediated Ca ${ }^{2+}$ influx in motoneurons, combined with their low $\mathrm{Ca}^{2+}$ buffering capacities, may explain the observation that AMPA receptor activation triggers much larger increases in cytoplasmic $\left[\mathrm{Ca}^{2+}\right]$ in motoneurons than in other spinal neurons (Carriedo et al., 1996, 2000). This large rise in intracellular $\left[\mathrm{Ca}^{2+}\right]$ in motoneurons during AMPA receptor activation may lead to mitochondrial $\mathrm{Ca}^{2+}$ overload, generation of reactive oxidant species, and cell death (Carriedo et al., 2000).

Recent work on NMDA receptor-mediated injury indicates that localized $\left[\mathrm{Ca}^{2+}\right]$ increases in submembrane domains closely surrounding NMDA receptors may be more critical in the induction of toxicity than the overall cytoplasmic $\left[\mathrm{Ca}^{2+}\right]$ increase, because of physical coupling of NMDA receptors to molecular triggers of $\mathrm{Ca}^{2+}$-dependent toxicity (Sattler et al., 1999). If, similarly, certain $\mathrm{Ca}^{2+}$-dependent neurotoxic cascades are physically located in the immediate vicinity of AMPA receptors, localized submembrane $\left[\mathrm{Ca}^{2+}\right]$ increases might be more crucial in the induction of AMPA receptor-mediated toxicity than the general elevation of cytoplasmic $\left[\mathrm{Ca}^{2+}\right]$. Such a mechanism would further enhance the importance of AMPA receptor current density as a predictor of AMPA receptor-mediated toxicity, because localized $\left[\mathrm{Ca}^{2+}\right]$ increases in submembrane regions would correlate better with AMPA receptor-mediated $\mathrm{Ca}^{2+}$ entry per cell membrane area than with $\mathrm{Ca}^{2+}$ entry per cell volume.

As shown in our toxicity experiments, pharmacological reduction of AMPA receptor current density in motoneurons to the same average level as in dorsal horn neurons essentially eliminates the difference in vulnerability to AMPA receptor agonists between the two cell populations. Therefore, the difference in AMPA receptor current density between motoneurons and dorsal horn neurons may be sufficient to explain their differential susceptibility to AMPA receptor-mediated injury in this culture model. To which extent these in vitro findings can be extrapolated to the intact human spinal cord remains an open question.

In conclusion, this study demonstrates that the selective vulnerability of cultured motoneurons to AMPA receptor agonists is determined, at least in part, at the level of AMPA receptormediated ion entry and suggests that the presence of a high density of functional AMPA receptors, rather than preferential expression of a unique AMPA receptor subtype, may account for selective motoneuron vulnerability in this model. In addition, given the evidence for a role for AMPA receptor-mediated excitotoxicity in the pathogenesis of ALS (Rothstein, 1996), the present findings may be relevant to selective motoneuron degeneration in human motoneuron disease. 


\section{REFERENCES}

Banke TG, Bowie D, Lee H, Huganir RL, Schousboe A, Traynelis SF (2000) Control of GluR1 AMPA receptor function by cAMP-dependent protein kinase. J Neurosci 20:89-102.

Bar-Peled O, O’Brien RJ, Morrison JH, Rothstein JD (1999) Cultured motoneurons possess calcium-permeable AMPA receptors. NeuroReport 10:855-859.

Bleakman D, Ballyk BA, Schoepp DD, Palmer AJ, Bath CP, Sharpe EF, Woolley ML, Bufton HR, Kamboj RK, Tarnawa I, Lodge D (1996) Activity of 2,3-benzodiazepines at native rat and recombinant human glutamate receptors in vitro: stereospecificity and selectivity profiles. Neuropharmacology 35:1689-1702.

Brorson JR, Manzolillo PA, Gibbons SJ, Miller RJ (1995) AMPA receptor desensitization predicts the selective vulnerability of cerebellar Purkinje cells to excitotoxicity. J Neurosci 15:4515-4524.

Brorson JR, Zhang Z, Vandenberghe W (1999) $\mathrm{Ca}^{2+}$ permeation of AMPA receptors in cerebellar neurons expressing Glu receptor 2. J Neurosci 19:9149-9159.

Carriedo SG, Yin HZ, Weiss JH (1996) Motor neurons are selectively vulnerable to AMPA/KA receptor-mediated injury in vitro. J Neurosci 16:4069-4079.

Carriedo SG, Sensi SL, Yin HZ, Weiss JH (2000) AMPA exposures induce mitochondrial $\mathrm{Ca}^{2+}$ overload and $\mathrm{ROS}$ generation in spinal motor neurons in vitro. J Neurosci 20:240-250.

Carroll RC, Beattie EC, Xia H, Lüscher C, Altschuler Y, Nicoll RA, Malenka RC, von Zastrow M (1999) Dynamin-dependent endocytosis of ionotropic glutamate receptors. Proc Natl Acad Sci USA 96:14112-14117.

Derkach V, Barria A, Soderling TR (1999) $\mathrm{Ca}^{2+} /$ calmodulin-kinase II enhances channel conductance of $\alpha$-amino-3-hydroxy-5-methyl-4 isoxazolepropionate type glutamate receptors. Proc Natl Acad Sci USA 96:3269-3274.

Geiger JR, Melcher T, Koh DS, Sakmann B, Seeburg PH, Jonas P, Monyer $\mathrm{H}$ (1995) Relative abundance of subunit mRNAs determines gating and $\mathrm{Ca}^{2+}$ permeability of AMPA receptors in principal neurons and interneurons in rat CNS. Neuron 15:193-204.

Greig A, Donevan SD, Mujtaba TJ, Parks TN, Rao MS (2000) Characterization of the AMPA-activated receptors present on motoneurons. J Neurochem 74:179-191.

Hamill OP, Marty A, Neher E, Sakmann B, Sigworth FJ (1981) Improved patch-clamp techniques for high-resolution current recording from cells and cell-free membrane patches. Pflügers Arch 391:85-100.

Hartley DM, Kurth MC, Bjerkness L, Weiss JH, Choi DW (1993) Glutamate receptor-induced ${ }^{45} \mathrm{Ca}^{2+}$ accumulation in cortical cell culture correlates with subsequent neuronal degeneration. J Neurosci 13:1993-2000.

Häusser M, Roth A (1997) Dendritic and somatic glutamate receptor channels in rat cerebellar Purkinje cells. J Physiol (Lond) 501:77-95.

Hille B (1984) Ionic channels of excitable membranes. Sunderland, MA: Sinauer.

Huettner JE, Stack E, Wilding TJ (1998) Antagonism of neuronal kainate receptors by lanthanum and gadolinium. Neuropharmacology 37:1239-1247.

Hugon J, Vallat JM, Spencer PS, Leboutet MJ, Barthe D (1989) Kainic acid induces early and delayed degenerative neuronal changes in rat spinal cord. Neurosci Lett 104:258-262.

Ikonomidou C, Qin Qin Y, Labruyere J, Olney JW (1996) Motor neuron degeneration induced by excitotoxin agonists has features in common with those seen in the SOD-1 transgenic mouse model of amyotrophic lateral sclerosis. J Neuropathol Exp Neurol 55:211-224.

Jakowec MW, Yen L, Kalb RG (1995) In situ hybridization analysis of AMPA receptor subunit gene expression in the developing rat spinal cord. Neuroscience 67:909-920.

Kiskin NI, Krishtal OA, Tsyndrenko A (1986) Excitatory amino acid receptors in hippocampal neurons: kainate fails to desensitize them. Neurosci Lett 63:225-230.

Koike M, Tsukada S, Tsuzuki K, Kijima H, Ozawa S (2000) Regulation of kinetic properties of GluR2 AMPA receptor channels by alternative splicing. J Neurosci 20:2166-2174.

Lambolez B, Ropert N, Perrais D, Rossier J, Hestrin S (1996) Correlation between kinetics and RNA splicing of $\alpha$-amino-3-hydroxy-5methylisoxazole-4-propionic acid receptors in neocortical neurons. Proc Natl Acad Sci USA 93:1797-1802.

Li P, Wilding TJ, Kim SJ, Calejesan AA, Huettner JE, Zhuo M (1999) Kainate-receptor-mediated sensory synaptic transmission in mammalian spinal cord. Nature 397:161-164.

Lu YM, Yin HZ, Chiang J, Weiss JH (1996) $\mathrm{Ca}^{2+}$-permeable AMPA/ kainate and NMDA channels: high rate of $\mathrm{Ca}^{2+}$ influx underlies potent induction of injury. J Neurosci 16:5457-5465.

Mosbacher J, Schoepfer R, Monyer H, Burnashev N, Seeburg PH, Ruppersberg JP (1994) A molecular determinant for submillisecond desensitization in glutamate receptors. Science 266:1059-1062.

O'Brien RJ, Fischbach GD (1986) Characterization of excitatory amino acid receptors expressed by embryonic chick motoneurons in vitro. J Neurosci 6:3275-3283.

Palecek J, Lips MB, Keller BU (1999) Calcium dynamics and buffering in motoneurones of the mouse spinal cord. J Physiol (Lond) 520:485-502.

Partin KM, Patneau DK, Mayer ML (1994) Cyclothiazide differentially modulates desensitization of $\alpha$-amino-3-hydroxy-5-methylisoxazolepropionic acid receptor splice variants. Mol Pharmacol 46:129-138.

Patneau DK, Mayer ML (1991) Kinetic analysis of interactions between kainate and AMPA: evidence for activation of a single receptor in mouse hippocampal neurons. Neuron 6:785-798.

Patneau DK, Vyklicky L, Mayer ML (1993) Hippocampal neurons exhibit cyclothiazide-sensitive rapidly desensitizing responses to kainate. J Neurosci 13:3496-3509.

Raman IM, Trussell LO (1992) The kinetics of the response to glutamate and kainate in neurons of the avian cochlear nucleus. Neuron 9:173-186.

Raman IM, Zhang S, Trussell LO (1994) Pathway-specific variants of AMPA receptors and their contribution to neuronal signaling. J Neurosci 14:4998-5010

Rothstein JD (1996) Excitotoxicity hypothesis. Neurology 47[Suppl 2]:S19-S25.

Rothstein JD, Jin L, Dykes-Hoberg M, Kuncl RW (1993) Chronic inhibition of glutamate uptake produces a model of slow neurotoxicity. Proc Natl Acad Sci USA 90:6591-6595.

Rothstein JD, Van Kammen M, Levey AI, Martin LJ, Kuncl RW (1995) Selective loss of glial glutamate transporter GLT-1 in amyotrophic lateral sclerosis. Ann Neurol 38:73-84.

Sather W, Dieudonné S, MacDonald J, Ascher P (1992) Activation and desensitization of $N$-methyl-D-aspartate receptors in nucleated outsideout patches from mouse neurones. J Physiol (Lond) 450:643-672.

Sattler R, Xiong Z, Lu W, Hafner M, MacDonald JF, Tymianski M (1999) Specific coupling of NMDA receptor activation to nitric oxide neurotoxicity by PSD-95 protein. Science 284:1845-1848.

Smith DO, Franke C, Rosenheimer JL, Zufall F, Hatt H (1991) Desensitization and resensitization rates of glutamate-activated channels may regulate motoneuron excitability. J Neurophysiol 66:1166-1175.

Sommer B, Keinänen K, Verdoorn TA, Wisden W, Burnashev N, Herb A, Köhler M, Tagaki T, Sakmann B, Seeburg PH (1990) Flip and flop: a cell-specific functional switch in glutamate-operated channels of the CNS. Science 249:1580-1585.

Spruston N, Jonas P, Sakmann B (1995) Dendritic glutamate receptor channels in rat hippocampal CA3 and CA1 pyramidal neurons. J Physiol (Lond) 482:325-352.

Swanson GT, Kamboj SK, Cull-Candy SG (1997) Single-channel properties of recombinant AMPA receptors depend on RNA editing, splice variation, and subunit composition. J Neurosci 17:58-69.

Swope SL, Moss SI, Raymond LA, Huganir RL (1999) Regulation of ligand-gated ion channels by protein phosphorylation. Adv Second Messenger Phosphoprotein Res 33:49-78.

Tölle TR, Berthele A, Zieglgänsberger W, Seeburg PH, Wisden W (1993) The differential expression of 16 NMDA and non-NMDA receptor subunits in the rat spinal cord and in periaqueductal gray. J Neurosci 13:5009-5028.

Tomiyama M, Rodriguez-Puertas R, Cortes R, Christnacher A, Sommer B, Pazos A, Palacios JM, Mengod G (1996) Differential regional distribution of AMPA receptor subunit messenger RNAs in the human spinal cord as visualized by in situ hybridization. Neuroscience 75:901-915.

Trussell LO, Fischbach GD (1989) Glutamate receptor desensitization and its role in synaptic transmission. Neuron 3:209-218.

Trussell LO, Thio LL, Zorumski CF, Fischbach GD (1988) Rapid desensitization of glutamate receptors in vertebrate central neurons. Proc Natl Acad Sci USA 85:4562-4566.

Vandenberghe W, Van Den Bosch L, Robberecht W (1998) Glial cells potentiate kainate-induced neuronal death in a motoneuron-enriched coculture system. Brain Res 807:1-10.

Vandenberghe W, Robberecht W, Brorson JR (2000) AMPA receptor calcium permeability, GluR2 expression, and selective motoneuron vulnerability J Neurosci 20:123-132.

Van Den Bosch L, Vandenberghe W, Klaassen H, Van Houtte E, Robberecht W (2000) $\mathrm{Ca}^{2+}$-permeable AMPA receptors and selective vulnerability of motor neurons. J Neurol Sci, in press.

Williams TL, Day NC, Ince PG, Kamboj RK, Shaw PJ (1997) Calciumpermeable alpha-amino-3-hydroxy-5-methyl-4-isoxazole propionic acid receptors: a molecular determinant of selective vulnerability in amyotrophic lateral sclerosis. Ann Neurol 42:200-207.

Yamada KA, Tang C-M (1993) Benzothiazides inhibit rapid glutamate receptor desensitization and enhance glutamatergic synaptic currents. J Neurosci 13:3904-3915.

Zorumski CF, Thio LL, Clark GD, Clifford DB (1990) Blockade of desensitization augments quisqualate excitotoxicity in hippocampal neurons. Neuron 5:61-66. 